\section{Regards sur l'économie allemande}

Bulletin économique du CIRAC

113 | 2014

Varia

\title{
Salaires : 19,65 $€$ bruts horaires moyens en 2013
}

Isabelle Bourgeois

\section{OpenEdition}

Journals

Édition électronique

URL : http://journals.openedition.org/rea/4699

DOI : 10.4000/rea.4699

ISSN : 1965-0787

Éditeur

CIRAC

Édition imprimée

Date de publication : 15 juillet 2014

Pagination : 44

ISSN : 1156-8992

\section{Référence électronique}

Isabelle Bourgeois, «Salaires : 19,65€ bruts horaires moyens en 2013 », Regards sur l'économie allemande [En ligne], 113 | juillet 2014, mis en ligne le 17 juillet 2016, consulté le 15 septembre 2020 URL : http://journals.openedition.org/rea/4699

Ce document a été généré automatiquement le 15 septembre 2020.

(c) CIRAC 


\title{
Salaires : $19,65 €$ bruts horaires moyens en 2013
}

\author{
Isabelle Bourgeois
}

1 En 2013, le salaire brut horaire moyen perçu par les actifs occupés à temps plein ou partiel dans l'industrie et les services s'élevait à 19,65€ (hors primes et versements exceptionnels) en moyenne allemande. Or comme toujours, cette moyenne recouvre des disparités importantes selon les fonctions exercées et les branches; mais aussi selon les Länder puisque, si les salaires sont fixés au sein de chaque branche et conformément à son évolution, ils tiennent compte également de la donne régionale en matière de compétitivité.

Salaires bruts horaires moyens (en $€$ ) versés en Allemagne en 2013

\begin{tabular}{|c|c|c|c|c|c|c|}
\hline & $\begin{array}{l}\text { Moyenne } \\
\text { générale }\end{array}$ & $\begin{array}{l}\text { Fonctions } \\
\text { de } \\
\text { direction }\end{array}$ & $\begin{array}{l}\text { Techniciens } \\
\text { supérieurs }\end{array}$ & Techniciens & $\begin{array}{l}\text { Formation } \\
\text { acquise } \\
\text { sur le } \\
\text { terrain }\end{array}$ & $\begin{array}{l}\text { Sans } \\
\text { qualification }\end{array}$ \\
\hline RFA & 19,65 & 35,53 & 23,66 & 16,72 & 13,60 & 11,53 \\
\hline Länder Ouest & 20,40 & 36,31 & 24,29 & 17,43 & 14,12 & 11,80 \\
\hline $\begin{array}{l}\text { Bade- } \\
\text { Wurtemberg }\end{array}$ & 21,23 & 36,77 & 25,01 & 18,36 & 15,15 & 13,14 \\
\hline Basse-Saxe & 18,82 & 33,82 & 22,95 & 16,83 & 13,73 & 11,51 \\
\hline Bavière & 20,60 & 37,21 & 24,53 & 17,29 & 14,08 & 11,73 \\
\hline Berlin & 18,71 & 32,90 & 21,90 & 15,62 & 11,68 & 9,88 \\
\hline Brême & 20,60 & 34,13 & 24,41 & 18,36 & 15,23 & 11,67 \\
\hline
\end{tabular}




\begin{tabular}{|l|l|l|l|l|l|l|}
\hline Hambourg & 22,12 & 37,45 & 25,93 & 18,18 & 13,57 & 10,94 \\
\hline Hesse & 21,65 & 38,94 & 25,93 & 18,05 & 14,19 & 11,74 \\
\hline $\begin{array}{l}\text { Rhénanie du } \\
\text { Nord-Westph. }\end{array}$ & 20,54 & 36,68 & 24,10 & 17,47 & 14,16 & 11,53 \\
\hline $\begin{array}{l}\text { Rhénanie- } \\
\text { Palatinat }\end{array}$ & 19,77 & 35,21 & 23,31 & 17,09 & 14,13 & 11,43 \\
\hline Sarre & 19,36 & 33,85 & 23,06 & 17,26 & 15,89 & 12,07 \\
\hline $\begin{array}{l}\text { Schleswig- } \\
\text { Holstein }\end{array}$ & 18,17 & 31,82 & 22,96 & 16,13 & 12,71 & 10,82 \\
\hline Länder Est & 15,30 & $\mathbf{2 9 , 5 2}$ & $\mathbf{1 9 , 2 7}$ & $\mathbf{1 3 , 3 1}$ & $\mathbf{1 0 , 8 5}$ & $\mathbf{9 , 6 1}$ \\
\hline Brandebourg & 15,84 & 30,84 & 19,95 & 13,71 & 10,88 & 9,75 \\
\hline $\begin{array}{l}\text { Mecklembourg- } \\
\text { Poméranie }\end{array}$ & 15,02 & 28,23 & 18,95 & 12,99 & 10,48 & 9,07 \\
\hline Saxe & 15,38 & 29,23 & 19,37 & 13,28 & 11,01 & 9,85 \\
\hline Saxe-Anhalt & 15,09 & 29,80 & 19,12 & 13,23 & 10,77 & 9,48 \\
\hline Thuringe & 15,02 & 29,41 & 18,75 & 13,28 & 10,84 & 9,51 \\
\hline
\end{tabular}

Source des données : Destatis, communiqué n²22 du 24-06-2014. NB : temps plein et temps partiel confondus, hors primes.

2 Quant aux moyennes, elles reflètent également la structure de l'activité dans chaque Land : plus la part de l'industrie ou du secteur banque/assurance (les mieux rémunérés) est grande, plus la moyenne est élevée. Les plus faibles sont ainsi relevées dans les nouveaux Länder, ce qui est dû entre autres au fait qu'on y compte moins de fonctions dirigeantes et plus de services 'primaires' (faiblement qualifiés) que dans les Länder de l'ouest (voir REA 98-99/2010). Les moyennes les plus élevées s'observent dans les Länder où se mêlent industrie et services hautement qualifiés: Hambourg, Hesse et BadeWurtemberg.

\section{INDEX}

Mots-clés : salaire 